University of Nebraska - Lincoln

DigitalCommons@University of Nebraska - Lincoln

Faculty Papers and Publications in Animal

Science

Animal Science Department

1998

\title{
Evaluation of the Ovine Callipyge Locus: II. Genotypic Effects on Growth, Slaughter, and Carcass Traits
}

\author{
B. A. Freking \\ U.S. Meat Animal Research Center, brad.freking@ars.usda.gov
}

J. W. Keele

Roman L. Hruska U.S. Meat Animal Research Center, USDA-ARS, Clay Center, NE

Merlyn K. Nielsen

University of Nebraska-Lincoln, mnielsen1@unl.edu

Kreg A. Leymaster

University of Nebraska-Lincoln, kleymaster2@unl.edu

Follow this and additional works at: https://digitalcommons.unl.edu/animalscifacpub

Part of the Animal Sciences Commons

Freking, B. A.; Keele, J. W.; Nielsen, Merlyn K.; and Leymaster, Kreg A., "Evaluation of the Ovine Callipyge Locus: II. Genotypic Effects on Growth, Slaughter, and Carcass Traits" (1998). Faculty Papers and Publications in Animal Science. 499.

https://digitalcommons.unl.edu/animalscifacpub/499

This Article is brought to you for free and open access by the Animal Science Department at DigitalCommons@University of Nebraska - Lincoln. It has been accepted for inclusion in Faculty Papers and Publications in Animal Science by an authorized administrator of DigitalCommons@University of Nebraska Lincoln. 


\section{Evaluation of the Ovine Callipyge Locus: II. Genotypic Effects on Growth, Slaughter, and Carcass Traits ${ }^{1,2}$}

\section{B. A. Freking*,t,3,4, J. W. Keele*, M. K. Nielsent, and K. A. Leymaster*}

*Roman L. Hruska U.S. Meat Animal Research Center, ARS, USDA, Clay Center, NE $68933-0166$ and tDepartment of Animal Science, University of Nebraska-Lincoln 68583-0908

\begin{abstract}
A resource flock of $362 F_{2}$ lambs provided phenotypic and genotypic data to estimate effects of callipyge (CLPG) genotypes on growth, slaughter, and carcass traits. Lambs were serially slaughtered in six groups at 3-wk intervals starting at 23 wk of age to allow comparisons at different end points. Probabilities of CLPG genotypes were calculated at a position $86 \mathrm{CM}$ from the most centromeric marker of chromosome 18. A contrast of CLPG genotypic effects, based on the paternal polar overdominance model, was used to evaluate callipyge and normal phenotypes. Relationships of traits with slaughter age, carcass weight, or 12th-rib fat depth for callipyge and normal phenotypic groups were estimated by regression. Callipyge and normal lambs did not differ for growth traits measured from birth to slaughter. Callipyge lambs produced $55.9 \%$ of live weight as chilled carcass weight compared with $51.7 \%$ for normal lambs at the same mean live weight of $48.32 \mathrm{~kg}$. Lighter pelt, kidney-pelvic fat, and liver weights contributed to this advantage of callipyge lambs for dressing percentage $(P<.001)$. Estimated accretion rates of carcass protein at the mean slaugh-

ter age were 12.5 and $10.2 \mathrm{~g} / \mathrm{d}$ for callipyge and normal carcasses, respectively. Corresponding values for carcass fat were 35.2 and $42.1 \mathrm{~g} / \mathrm{d}$. Compositional differences in favor of callipyge carcasses were de tected at constant values of slaughter age, carcass weight, and 12th-rib fat depth. Callipyge carcasses had $2.56 \mathrm{~kg}$ greater fat-free lean and $1.39 \mathrm{~kg}$ less fat than normal carcasses at the same mean age of 214.9 $d(P<.001)$. The majority of these differences were established before the initial group was slaughtered and were maintained as age increased. Callipyge carcasses consisted of $24.3 \%$ fat and $71.3 \%$ fat-free lean, compared with 31.5 and $64.0 \%$ for normal carcasses at $25.6 \mathrm{~kg}$ of carcass weight. When evaluated at $.49 \mathrm{~cm}$ of 12th-rib fat depth, callipyge lambs were $15.4 \mathrm{~d}$ older and produced $4.1 \mathrm{~kg}$ heavier carcasses with $4.3 \%$ less fat $(P<.001)$. Effects of CLPG genotypic groups on carcass composition were greater than virtually all reported breed substitution effects. Use of the CLPG mutant allele in structured mating systems can dramatically increase production of lean lamb.
\end{abstract}

Key Words: Callipyge, Sheep, Carcass Composition, Genotypes

(01998 American Society of Animal Science. All rights reserved.

J. Anim. Sci. 1998. 76:2549-2559

\section{Introduction}

The existence of an apparent single gene with dramatic effects on carcass traits of sheep was first reported by J ackson and Green (1993) and J ackson et

\footnotetext{
${ }^{1}$ Published as paper no. 12147, J ournal Ser. Nebraska Agric. Res. Div., Univ. of Nebraska, Lincoln 68583-0908.

${ }^{2}$ We acknowledge Steven Shackelford, Meats Research Unit, U.S. Meat Animal Research Center, for assignment of leg muscling scores for carcasses.

${ }^{3}$ Partly supported by the Center for Biotechnology, Univ. of Nebraska-Lincoln and the American Sheep Industry National Wool Growers Memorial Fellowship.

${ }^{4}$ To whom correspondence should be addressed. Phone: 402/ 762-4278; fax: 402/762-4173.

Received February 23, 1998.

Accepted J une 17, 1998.
}

al. (1993a,b). Qualitative and quantitative methods from independent studies positioned the callipyge (CLPG) locus to the terminal region of chromosome 18 and provided evidence to support the paternal polar overdominance model of gene action (Cockett et al., 1994, 1996; Freking et al., 1998). Previous research by other scientists estimated callipyge phenotypic effects from data collected on lambs produced by heterozygous rams and noncarrier ewes. Each resulting lamb represented one of two CLPG genotypes and was subjectively classified as expressing either the callipyge or the normal phenotype. Statistical inferences of phenotypic effects applied to restricted ranges of slaughter end points and relationships of traits with slaughter age or carcass weight within phenotypes were not fitted. Various markets place different emphasis on carcass weight, subcutaneous fat depth, or carcass conformation. Estimates of effects of all four 
CLPG genotypes, with inferences over wide ranges of biological and economical end points, are needed to provide complete information to sheep industries in the United States and abroad. Our objective was to estimate effects of CLPG genotypes, inferred from flanking DNA-based markers, on growth, slaughter, and carcass traits recorded throughout an experiment of serial slaughter design.

\section{Materials and Methods}

\section{Animal Population and Phenotypic Data}

Establishment of a resource population of lambs and description of phenotypic data collected at the Roman L. Hruska U.S. Meat Animal Research Center (MARC) were described in detail by Freking et al. (1998). In this manuscript, the abbreviation CLPG is used to describe the gene representing all possible alleles, whereas callipyge is used to describe the unique phenotypic expression associated with a specific genotype. Briefly, Dorset rams that exhibited the callipyge phenotype were mated to Romanov ewes. Callipyge $F_{1}$ rams were inter semated to $F_{1}$ ewes (about two-thirds were classified as expressing the callipyge phenotype) for two breeding seasons. The resulting $F_{2}$ progeny, born in 1994 and 1995, were slaughtered to obtain chemical composition and traditional carcass data ( $n=362$ ). To assign lambs to slaughter groups, each lamb was subjectively evaluated for expression of the callipyge or normal phenotype at 20 wk of age. Within sex-phenotype subgroups, sample lambs representative of variation in birth date were assigned to each of six slaughter groups. The $F_{2}$ ewe and wether lambs were serially slaughtered at 23 , $26,29,32,35$, and $38 \mathrm{wk}$ of age ( $\mathrm{n}=$ approximately 30 per age group per year) at the MARC abattoir. To evaluate the distribution of carcass components, the right side was cut into three sections: anterior (shoulder, neck, foreshank, and breast), midsection (loin, rib, and flank), and posterior (sirloin, leg, and hindshank). The anterior section and midsection were separated between the 5th and 6th ribs. The posterior section was separated from the midsection between the second-to-last and last lumbar vertebrae. Water, fat (ether extract), protein $(N \times 6.25)$, and ash components were directly determined for each section (AOAC, 1990).

\section{Genotypic Probabilities}

Genotypic data were collected for 25 marker loci that spanned 87.2 centimorgans (CM) of ovine chromosome 18. Conditional probabilities of CLPG genotypes were calculated for each $\mathrm{F}_{2}$ lamb as a function of the recombination rate between the two informative marker loci that flank position $86 \mathrm{cM}$, the predicted position of CLPG relative to the most centromeric marker in the current linkage group. Descriptions of the methods to calculate conditional probabilities and to position CLPG were provided by Freking et al. (1998). Probabilities of CC, CN, NC, and NN genotypes were calculated for each lamb, where C represents the mutant CLPG allele, $\mathbf{N}$ represents the normal allele(s), and the paternal allele of the genotype is listed first. Because CL PG genotypes were predicted from flanking marker information, probabilities ranged continuously between zero and one. For example, an $\mathrm{F}_{2}$ lamb had probabilities of .0003, .9995, .0000 , and .0002 for CC, CN, NC, and NN genotypes, respectively. Genotypic probabilities were completely confounded within animal, summing to one.

\section{Statistical Analyses}

All traits were defined on an individual-lamb basis. The statistical model for slaughter and carcass traits included effects of year, sex, and sire to partially account for environmental and polygenic effects. Regressions on CC, CN, NC, and $\mathbf{N N}$ probabilities ( NN effect was set to zero to remove dependency) and genotype-specific second-order polynomials of covariates (slaughter age, carcass weight, or 12th-rib fat depth) were also estimated. Weights at weaning, at 98, and at $140 \mathrm{~d}$ were preadjusted for variation in age; the statistical model for these growth traits included effects of year, sex, and sire, and regressions on CC, $\mathbf{C N}, \mathbf{N C}$, and $\mathbf{N N}$ probabilities. The distribution of carcass protein was evaluated by regressing weight of anterior, middle, or posterior section protein on weight of carcass protein. The model included effects of year, sex, and sire; regressions on CC, CN, NC, and NN probabilities; and genotype-specific second-order polynomials of carcass protein. The distribution of carcass fat was analyzed with an analogous model. Preliminary analyses of all traits indicated that two-way interactions between discrete effects and interactions of sex with genotypic probabilities were not significant and were thus ignored in subsequent analyses.

The paternal polar overdominance model of gene action was tested by fitting a 3-df contrast of regression and linear and quadratic polynomial effects involving CC, CN, NC, and $\mathbf{N} \mathbf{N}$ genotypes $(-1,3,-1$, and -1 , respectively). For traits presented herein, the polar overdominance contrast is the only biologically relevant comparison, because orthogonal contrasts involving CC, $\mathbf{C N}, \mathbf{N C}$, and $\mathbf{N} \mathbf{N}$ genotypic effects for additive $(1,0,0,-1)$ and maternal dominance $(-1,0$, 2 , and -1 ) models of gene action were not significant. Consequently, the callipyge phenotype is the effect of the $\mathbf{C N}$ genotype, whereas the normal phenotype is due to $\mathbf{C C}, \mathbf{N C}$, and $\mathbf{N N}$ genotypes. Owing to the lack of evidence for differential effects among CC, NC, and NN genotypes, the additive and maternal dominance genetic effects were excluded to achieve a parsimonious model including only the polar overdominance effect. The polar overdominance effect was estimated 
Table 1. Least squares means of polar overdominance genotypic groups for growth traits

\begin{tabular}{|c|c|c|c|c|c|}
\hline Trait & $\begin{array}{c}\text { Callipyge } \\
\text { (CN genotype) }\end{array}$ & $\begin{array}{c}\text { Normal } \\
\text { (CC, NC, NN genotypes) }\end{array}$ & $\begin{array}{l}\text { Effect of callipyge } \\
\text { in residual SD }\end{array}$ & $\begin{array}{l}\text { Percentage } \\
\text { variation }^{\mathrm{a}}\end{array}$ & $\begin{array}{l}\text { Contrast } \\
\text { P-value }\end{array}$ \\
\hline Birth weight, kg & 4.02 & 4.02 & .00 & .002 & .92 \\
\hline Adjusted weaning weight, $\mathrm{kg}^{\mathrm{b}}$ & 16.99 & 16.80 & .05 & .05 & .65 \\
\hline Adjusted 98-d weight, $\mathrm{kg}^{\mathrm{c}}$ & 26.86 & 26.94 & -.02 & .006 & .88 \\
\hline Adjusted $140-\mathrm{d}$ weight, $\mathrm{kg}^{\mathrm{d}}$ & 36.87 & 36.61 & .05 & .05 & .67 \\
\hline
\end{tabular}

aDifference in residual sums of squares on a percentage basis accounted for by $1 \mathrm{df}$ associated with polar overdominance contrast.

${ }^{b}$ Adjusted to the average weaning age of $61.6 \mathrm{~d}$ using the individual's average daily gain during the first postweaning interval.

'Adjusted to $98 \mathrm{~d}$ of age using the individual's average daily gain from weaning to the 98-d weight.

dAdjusted to $140 \mathrm{~d}$ of age using the individual's average daily gain from the 98- to 140-d weights.

by regression on the difference between the $\mathbf{C N}$ probability and the pooled probability of $\mathbf{C C}, \mathbf{N C}$, and NN genotypes. The interaction of this effect with linear and quadratic covariate terms was also estimated.

Relationships of response variables with covariates (slaughter age, carcass weight, 12th-rib fat depth, carcass protein, or carcass fat) for callipyge ( CN) and normal ( CC, NC, and NN) phenotypes (genotypes) were defined by second-order polynomial equations calculated from parsimonious models. Covariate values were coded as deviations from the mean of the covariate. Thus, intercept values represent means of callipyge and normal phenotypes at the mean of the covariate. Linear regression coefficients represent the change in response variable per unit change in the covariate at the mean of the covariate (e.g., accretion rate for slaughter age or composition of gain for carcass weight). Rates of change at values other than the covariate mean can be calculated from first derivatives of regression equations.

\section{Results}

\section{Growth Traits}

Least squares means of polar overdominance genotypic groups for growth traits from birth to $140 \mathrm{~d}$ of age are presented in Table 1 . No significant differences between CLPG genotypic groups were detected for body weight of lambs at any age. Birth weight of individual lambs averaged $4.02 \mathrm{~kg}$. Adjusted live weights at weaning, 98, and $140 \mathrm{~d}$ of age were calculated using the individual lamb's ADG during the adjacent postweaning interval. The 140-d weight was the final growth trait recorded on all animals before initiation of serial slaughter. Less than $1 \%$ of the variation of these traits was accounted for by the polar overdominance contrast.

\section{Relationships with Slaughter Age}

An experimentally controlled environmental factor was slaughter age. Intended slaughter ages ranged from 23 to 38 wk in intervals of 3 wk. Effects of polar overdominance genotypic groups at the mean slaughter age of $214.9 \mathrm{~d}$ are presented in Table 2 expressed as pooled residual SD units. The difference between genotypic groups in actual units at the mean slaughter age is simply the difference between intercept values. The variation attributed to the polar overdominance effect and its interactions with linear and quadratic terms of slaughter age ( $3 \mathrm{df}$ ) is presented as a difference in the residual sums of squares on a percentage basis relative to a model excluding these effects.

When evaluated at the mean age at slaughter, callipyge lambs weighed $1.2 \mathrm{~kg}$ less than normal lambs, but this difference was not statistically significant. However, carcass weight of callipyge lambs was $1.2 \mathrm{~kg}(\mathrm{P}<.05)$ heavier than that of normal lambs. The posterior section of the carcass was the only section that contributed significantly to the increase in carcass weight. Callipyge lambs had lighter pelts ( $\mathrm{P}<$ $.05)$, lighter livers $(P<.001)$, and less weight of kidney-pelvic fat $(P<.001)$ when compared at the mean slaughter age. Fat depths at the 12th rib ( $\mathrm{P}<$ $.001)$ and fourth sacral vertebra $(P<.01)$ were less for callipyge carcasses.

Several measures of carcass shape indicated that callipyge carcasses were more compact in skeletal structure and exhibited a more pronounced muscle shape. Length measurements taken along the spinal column and metacarpus indicated that callipyge carcasses were $1.65(\mathrm{P}<.001)$ and $.318(\mathrm{P}<.05) \mathrm{cm}$ shorter, respectively than normal carcasses at the same age. Estimates of carcass width at the widest points of the shoulder and rump indicated that anterior and posterior regions of callipyge carcasses were wider than normal carcasses $(P<.001)$. Longissimus muscle shape evaluated at the 12th-rib interface also indicated that width, depth, and surface area of this muscle were greater in callipyge carcasses than in normal contemporaries, of the same age $(P<.001)$. Leg conformation scores of callipyge lambs were significantly greater at all ages. The effect of callipyge phenotype on leg score was 4.15 residual SD, accounting for over $70 \%$ of the variation.

In general, differences between genotypic groups were established at the initial slaughter age, and these effects were maintained or increased as animals 
Table 2. Regression equations of slaughter and carcass traits on days of age by polar overdominance genotypic group ${ }^{a}$

\begin{tabular}{|c|c|c|c|c|c|c|c|c|}
\hline \multirow[b]{2}{*}{ Trait } & \multicolumn{3}{|c|}{ Callipyge ( $\mathbf{C N}$ genotype) } & \multicolumn{3}{|c|}{ Normal (CC, NC, NN genotypes) } & \multirow{2}{*}{$\begin{array}{l}\text { Effect of } \\
\text { callipyge in } \\
\text { residual SD }\end{array}$} & \multirow{2}{*}{$\begin{array}{l}\text { Percentage } \\
\text { variation }\end{array}$} \\
\hline & Intercept & Linear & Quadratic & Intercept & Linear & Quadratic & & \\
\hline $\begin{array}{l}\text { Live wt, } \mathrm{kg} \\
\text { Pelt wt, } \mathrm{kg} \\
\text { Liver wt, } \mathrm{kg} \\
\text { Kidney-pelvic fat, kg }\end{array}$ & $\begin{array}{r}47.612 \\
5.826 \\
.710 \\
1.034\end{array}$ & $\begin{array}{l}.109791 \\
.018174 \\
.001183 \\
.009317\end{array}$ & $\begin{array}{r}.000593 \\
-.000073 \\
.000003 \\
.000016\end{array}$ & $\begin{array}{r}48.812 \\
6.155 \\
.785 \\
1.330\end{array}$ & $\begin{array}{l}.122213 \\
.021736 \\
.000997 \\
.008257\end{array}$ & $\begin{array}{l}-.000141 \\
-.000099 \\
-.000013 \\
-.000016\end{array}$ & $\begin{array}{l}-.22 \\
-.39^{*} \\
-.61^{* * *} \\
-.82^{* * *}\end{array}$ & $\begin{array}{r}.33 \\
1.48 \\
2.96 \\
4.80\end{array}$ \\
\hline $\begin{array}{l}\text { Carcass weight, } \mathrm{kg} \\
\text { Anterior section } \\
\text { Middle section } \\
\text { Posterior section }\end{array}$ & $\begin{array}{r}26.733 \\
8.791 \\
8.473 \\
9.440\end{array}$ & $\begin{array}{l}.085428 \\
.026166 \\
.032633 \\
.026701\end{array}$ & $\begin{array}{l}.000116 \\
.000053 \\
.000062 \\
.000014\end{array}$ & $\begin{array}{r}25.526 \\
8.634 \\
8.291 \\
8.590\end{array}$ & $\begin{array}{l}.085934 \\
.028718 \\
.031855 \\
.025271\end{array}$ & $\begin{array}{l}-.000222 \\
-.000041 \\
-.000120 \\
-.000062\end{array}$ & $\begin{array}{l}.39^{*} \\
.15 \\
.15 \\
.85^{* * *}\end{array}$ & $\begin{array}{r}2.28 \\
.68 \\
1.21 \\
7.29\end{array}$ \\
\hline $\begin{array}{l}\text { Fat depth, } \mathrm{cm} \\
\text { 12th rib } \\
\text { Fourth sacral vertebra }\end{array}$ & $\begin{array}{r}.377 \\
1.369\end{array}$ & $\begin{array}{l}.002488 \\
.005881\end{array}$ & $\begin{array}{r}.000006 \\
-.000015\end{array}$ & $\begin{array}{r}.557 \\
1.570\end{array}$ & $\begin{array}{l}.003118 \\
.006095\end{array}$ & $\begin{array}{l}-.000012 \\
-.000011\end{array}$ & $\begin{array}{l}-.95 * * * \\
-.50^{* *}\end{array}$ & $\begin{array}{l}7.47 \\
2.57\end{array}$ \\
\hline $\begin{array}{l}\text { Carcass length, } \mathrm{cm} \\
\text { Metacarpus length, } \mathrm{cm} \\
\text { Shoulder width, cm } \\
\text { Rump width, cm }\end{array}$ & $\begin{array}{l}61.324 \\
19.044 \\
20.514 \\
23.343\end{array}$ & $\begin{array}{l}.045288 \\
.015647 \\
.026983 \\
.023069\end{array}$ & $\begin{array}{r}.000077 \\
-.000016 \\
-.000079 \\
.000026\end{array}$ & $\begin{array}{l}62.974 \\
19.362 \\
19.611 \\
22.061\end{array}$ & $\begin{array}{l}.052080 \\
.018003 \\
.026447 \\
.024985\end{array}$ & $\begin{array}{l}-.000011 \\
-.000012 \\
-.000109 \\
-.000128\end{array}$ & $\begin{array}{l}-.71^{* * *} \\
-.44^{*} \\
.72^{* * *} \\
1.22^{* * *}\end{array}$ & $\begin{array}{r}3.77 \\
1.89 \\
5.58 \\
16.63\end{array}$ \\
\hline $\begin{array}{l}\text { Longissimus muscle } \\
\text { Depth, } \mathrm{cm} \\
\text { Width, } \mathrm{cm} \\
\text { Area, } \mathrm{cm}^{2}\end{array}$ & $\begin{array}{r}3.912 \\
6.708 \\
20.501\end{array}$ & $\begin{array}{l}.003934 \\
.006704 \\
.041946\end{array}$ & $\begin{array}{r}.000030 \\
.000001 \\
-.000054\end{array}$ & $\begin{array}{r}3.264 \\
5.960 \\
15.096\end{array}$ & $\begin{array}{l}.003984 \\
.004118 \\
.028414\end{array}$ & $\begin{array}{r}.000046 \\
-.000056 \\
-.000048\end{array}$ & $\begin{array}{l}2.00^{* * *} \\
2.09 * * * \\
2.59 * * *\end{array}$ & $\begin{array}{l}34.98 \\
38.36 \\
45.56\end{array}$ \\
\hline$\underline{\text { Leg score }}^{c}$ & 14.790 & .001917 & .000121 & 10.913 & .001083 & -.000005 & $4.15^{* * *}$ & 72.39 \\
\hline
\end{tabular}

${ }^{a}$ Covariate values are deviations from the mean value of $214.9 \mathrm{~d}$ of age. The callipyge effect (actual units) at the mean slaughter age is the difference between callipyge and normal intercept values.

${ }^{b}$ Difference in residual sums of squares on a percentage basis accounted for by $3 \mathrm{df}$ associated with polar overdominance contrast.

${ }^{c}$ Average choice $=11$, average prime $=14$.

$* \mathrm{P}<.05$.

$* * \mathrm{P}<.01$

$* * * \mathrm{P}<.001$.

became older. Effects of genotypic group in residual SD at the mean slaughter age ranged from .15 unit for anterior and midsection weights to 4.15 units for leg score. A difference of .5 SD or greater was typical of traits associated with carcass shape and fat depth, whereas effects on longissimus dimensions were over 2 SD. Genotypic groups accounted for greater than $30 \%$ of the variation in longissimus traits, ranging from $.3 \%$ for live weight to $72 \%$ for leg score.

\section{Relationships with Carcass Weight}

Relationships of traits with slaughter age are partially associated with differences between genotypic groups in carcass weight. It is of biological and economical relevance to estimate relationships of traits with carcass weight for CLPG genotypic groups (Table 3). To produce $25.63 \mathrm{~kg}$ of carcass weight, normal lambs weighed $3.18 \mathrm{~kg}$ heavier than callipyge lambs $(P<.001)$. The relationship between chilled carcass weight and live weight at slaughter is presented in Figure 1. A 2-kg advantage ( $\mathrm{P}<.001)$ of callipygelambs in carcass weight was maintained over the entire range of live weight. The advantage in dressing percentage for callipyge lambs of 3.65 actual percentage units at the mean carcass weight of 25.63 $\mathrm{kg}$ is associated with significantly lighter weights of pelt $(.594 \mathrm{~kg})$, liver $(.096 \mathrm{~kg})$, and kidney-pelvic fat (.395 kg). When evaluated at the mean carcass weight, callipyge carcasses had $.465 \mathrm{~kg}$ heavier posterior-section weight, compensated by $.219 \mathrm{~kg}$ less anterior-section weight and $.254 \mathrm{~kg}$ less middlesection weight than did normal carcasses $(P<.001)$.

Measurements at the 12th rib and fourth sacral vertebra indicated less subcutaneous fat depth for callipyge carcasses than for normal carcasses of the same weight $(P<.001)$. Fat depth at the 12 th rib of callipyge carcasses was low over the entire range of carcass weights and did not exceed $.5 \mathrm{~cm}$ until carcass weight averaged $31.8 \mathrm{~kg}$, compared with normal carcasses that reached this same fat depth at $24.4 \mathrm{~kg}$.

When compared at the mean carcass weight, call ipyge carcasses were more muscular and compactly shaped as evaluated by various quantitative and subjective measures. Carcasses of callipyge lambs were $2.5 \mathrm{~cm}$ shorter along the spine and had $.56 \mathrm{~cm}$ shorter metacarpal bones than normal carcasses at the same weight of $25.63 \mathrm{~kg}(\mathrm{P}<.001)$. Callipyge carcasses were significantly wider at the shoulder and rump $(P<.001)$. Dimensions of the longissimus 
Table 3. Regression equations of slaughter and carcass traits on carcass weight by polar overdominance genotypic group ${ }^{a}$

\begin{tabular}{|c|c|c|c|c|c|c|c|c|}
\hline \multirow[b]{2}{*}{ Trait } & \multicolumn{3}{|c|}{ Callipyge ( CN genotype) } & \multicolumn{3}{|c|}{ Normal (CC, NC, NN genotypes) } & \multirow{2}{*}{$\begin{array}{l}\text { Effect of } \\
\text { callipyge in } \\
\text { residual SD }\end{array}$} & \multirow{2}{*}{$\begin{array}{l}\text { Percentage } \\
\text { variation }\end{array}$} \\
\hline & Intercept & Linear & Quadratic & Intercept & Linear & Quadratic & & \\
\hline Live wt, $\mathrm{kg}$ & 46.296 & 1.418604 & .009516 & 49.480 & 1.529320 & -.011398 & $-1.50 * * *$ & 2.53 \\
\hline Pelt wt, kg & 5.553 & .172222 & -.001369 & 6.147 & .208252 & -.002051 & $-.81^{* * *}$ & 5.01 \\
\hline Liver wt, kg & .689 & .021896 & -.000158 & .785 & .017426 & -.000404 & $-.95^{* * *}$ & 6.77 \\
\hline Kidney-pelvic fat, kg & .951 & .077704 & .000556 & 1.346 & .080548 & -.000318 & $-1.22 * * *$ & 9.74 \\
\hline Dressing percentage, \% & 56.638 & .475380 & -.020389 & 52.991 & .415796 & .002215 & $1.51 * * *$ & 15.33 \\
\hline \multicolumn{9}{|l|}{ Carcass weight, $\mathrm{kg}$} \\
\hline Anterior section & 8.495 & .312721 & -.001417 & 8.714 & .325915 & -.000253 & $-.55^{* * *}$ & .48 \\
\hline Middle section & 7.999 & .369289 & .003802 & 8.253 & .376703 & .001332 & $-.67 * * *$ & .25 \\
\hline Posterior section & 9.118 & .317805 & -.002175 & 8.653 & .296863 & -.001195 & $1.40 * * *$ & 1.67 \\
\hline \multicolumn{9}{|l|}{ Fat depth, cm } \\
\hline 12th rib & .339 & .022309 & .000660 & .543 & .034183 & .000550 & $-1.20 * * *$ & 12.74 \\
\hline Fourth sacral vertebra & 1.256 & .068141 & .000492 & 1.582 & .064631 & -.000024 & $-.92 * * *$ & 5.70 \\
\hline Carcass length, cm & 60.723 & .588267 & -.001588 & 63.254 & .581941 & -.009186 & $-1.79 * * *$ & 9.70 \\
\hline Metacarpus length, cm & 18.903 & .154943 & -.002832 & 19.465 & .170133 & -.002606 & $-.90 * * *$ & 5.37 \\
\hline Shoulder width, cm & 20.081 & .296344 & -.001552 & 19.661 & .320410 & -.003090 & $.53 * * *$ & 1.20 \\
\hline Rump width, cm & 23.131 & .303586 & -.005609 & 22.138 & .288666 & -.005885 & $1.98 * * *$ & 7.42 \\
\hline \multicolumn{9}{|l|}{ Longissimus muscle } \\
\hline Depth, cm & 3.922 & .059171 & -.002057 & 3.325 & .051105 & .000903 & $2.18^{* * *}$ & 25.53 \\
\hline Width, $\mathrm{cm}$ & 6.687 & .067781 & -.002140 & 5.935 & .040985 & -.001400 & $2.21 * * *$ & 30.93 \\
\hline Area, $\mathrm{cm}^{2}$ & 20.200 & .520774 & -.015585 & 15.197 & .348228 & -.000775 & $3.02 * * *$ & 34.87 \\
\hline Leg score ${ }^{c}$ & 15.074 & .085086 & -.010205 & 11.012 & .045262 & -.003703 & $4.53^{* * *}$ & 66.88 \\
\hline
\end{tabular}

${ }^{a}$ Covariate values are deviations from the mean value of $25.63 \mathrm{~kg}$ carcass weight. The callipyge effect (actual units) at the mean carcass weight is the difference between callipyge and normal intercept values.

${ }^{b}$ Difference in residual sums of squares on a percentage basis accounted for by $3 \mathrm{df}$ associated with polar overdominance contrast.

${ }^{\mathrm{C}}$ Average choice $=11$, average prime $=14$.

$* * * P<.001$.

muscle at the 12th rib indicated an advantage of 6.0 $\mathrm{mm}$ in depth and $7.5 \mathrm{~mm}$ in width for callipyge carcasses at the mean carcass weight $(P<.001)$. This resulted in a $5.0-\mathrm{cm}^{2}$ increase in surface area of the longissimus muscle that equated to a 3-SD effect in favor of callipyge lambs ( $P<.001)$. Analysis of leg muscling score revealed a 4.5-SD increase $(P<.001)$ for callipyge carcasses at the mean carcass weight, accounting for over $66 \%$ of the residual phenotypic variation.

\section{Carcass Composition}

Relationships of compositional traits with slaughter age, carcass weight, and 12th-rib fat depth were estimated (Table 4). Even though evidence from carcass and metacarpus length measurements indicated that callipyge lambs produced shorter, more compact carcasses, no differences in ash weight were detected at the mean age or carcass weight. Advantages of callipyge carcasses for greater fat-free lean (water + protein) and less fat $(P<.001)$ were apparent at the initial group, and these differences increased slightly as age increased (Figure 2 ). Protein accretion rates at the mean age were 12.5 and $10.2 \mathrm{~g} /$ $d$, respectively, for callipyge and normal carcasses.
Accretion rates of fat were 35.2 and $42.1 \mathrm{~g} / \mathrm{d}$ for callipyge and normal carcasses, respectively, at the mean age.

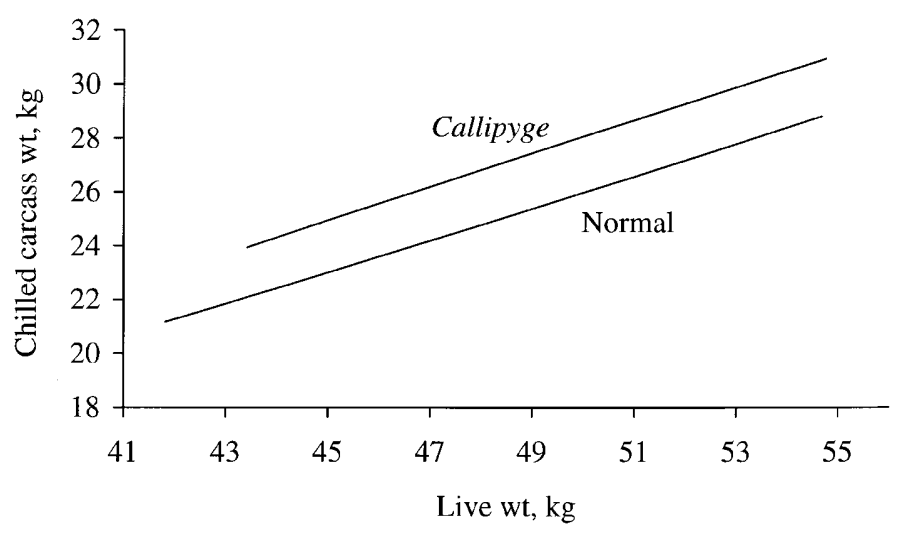

Figure 1. Relationship of carcass weight with live weight of callipyge (CN) and normal (CC, NC, NN) phenotypic (genotypic) groups. Prediction of callipyge carcass weights is based on the expression $27.013+$ $.618904 \mathrm{x}-.001668 \mathrm{x}^{2}$, where $\mathrm{x}$ is a deviation from 48.32 $\mathrm{kg}$. Prediction of normal carcass weights is based on the expression $24.960+.594297 x+.001412 x^{2}$, where $x$ is a deviation from $48.32 \mathrm{~kg}$. 
Table 4. Regression equations of compositional traits on age, carcass weight, and 12th-rib fat depth by polar overdominance genotypic group

\begin{tabular}{|c|c|c|c|c|c|c|c|c|}
\hline \multicolumn{9}{|l|}{ Days of age $e^{b}$} \\
\hline Carcass ash, kg & 1.180 & .002816 & -.000003 & 1.157 & .003432 & -.000023 & .16 & 1.39 \\
\hline Carcass fat, kg & 6.743 & .035189 & .000032 & 8.129 & .042069 & -.000092 & $-.89 * * *$ & 5.32 \\
\hline Carcass protein, kg & 4.466 & .012515 & .000018 & 3.833 & .010215 & -.000034 & $1.48 * * *$ & 19.21 \\
\hline Carcass water, kg & 14.318 & .035120 & .000078 & 12.389 & .030302 & -.000072 & $1.37 * * *$ & 17.87 \\
\hline Percentage fat-free lean & 70.435 & -.046607 & -.000297 & 63.772 & -.059251 & .000377 & $2.09 * * *$ & 31.89 \\
\hline \multicolumn{9}{|l|}{ Carcass weight ${ }^{c}$} \\
\hline Carcass ash, kg & 1.122 & .035807 & .000405 & 1.145 & .037349 & -.000097 & -.24 & .17 \\
\hline Carcass fat, kg & 6.206 & .372922 & .003379 & 8.065 & .483942 & .005983 & $-2.42 * * *$ & 13.28 \\
\hline Carcass protein, kg & 4.337 & .148043 & -.000892 & 3.873 & .114833 & -.000179 & $2.55^{* * *}$ & 10.20 \\
\hline Carcass water, kg & 13.945 & .445237 & -.002665 & 12.534 & .364529 & -.004187 & $2.36 * * *$ & 8.87 \\
\hline Carcass ash, kg & 1.249 & .500274 & -.202835 & 1.118 & .480851 & -.256362 & $.78 * * *$ & 6.19 \\
\hline Carcass fat, kg & 7.697 & 7.257568 & -1.321921 & 7.730 & 7.897414 & -2.174658 & -.02 & .07 \\
\hline Carcass protein, kg & 4.789 & 1.805380 & -1.272847 & 3.769 & 1.505564 & -.976793 & $2.03 * * *$ & 33.23 \\
\hline Carcass water, kg & 15.256 & 4.935972 & -3.766822 & 12.251 & 4.468956 & -3.068233 & $1.87 * * *$ & 30.21 \\
\hline Fat-free lean, kg & 20.044 & 6.741352 & -5.039668 & 16.020 & 5.974521 & -4.045027 & $1.92 * * *$ & 31.16 \\
\hline Percentage fat & 26.509 & 13.049550 & -5.185600 & 30.807 & 15.032210 & -6.107960 & $-1.54 * * *$ & 10.71 \\
\hline Percentage fat-free lean & 69.159 & -12.382254 & 4.511240 & 64.636 & -14.220312 & 5.676555 & $1.68 * * *$ & 12.49 \\
\hline Carcass wt, $\mathrm{kg}$ & 28.999 & 14.458992 & -6.574812 & 24.886 & 14.347874 & -6.498026 & $1.21 * * *$ & 12.14 \\
\hline Age, d & 227.872 & 87.178346 & -15.417472 & 212.454 & 98.480764 & -51.044216 & $.49 * *$ & 4.20 \\
\hline
\end{tabular}

aDifference in residual sums of squares on a percentage basis accounted for by $3 \mathrm{df}$ associated with polar overdominance contrast.

${ }^{b}$ Covariate values are deviations from the mean value of $214.9 \mathrm{~d}$ of age. The callipyge effect (actual units) at the mean slaughter age is the difference between callipyge and normal intercept values.

'Covariate values are deviations from the mean value of $25.63 \mathrm{~kg}$. The callipyge effect (actual units) at the mean carcass weight is the difference between callipyge and normal intercept values.

${ }^{\mathrm{d}}$ Covariate values are deviations from the mean value of $.491 \mathrm{~cm}$. The callipyge effect (actual units) at the mean 12 th-rib fat depth is the difference between callipyge and normal intercept values.

$* * \mathrm{P}<.01$.

$* * * \mathrm{P}<.001$.

At the mean carcass weight, a 1-kg increase in weight of callipyge carcasses consisted of $36 \mathrm{~g}$ ash, 373 $\mathrm{g}$ fat, $148 \mathrm{~g}$ protein, and $445 \mathrm{~g}$ water. Comparable values for normal carcasses were $37,484,115$, and 365 $\mathrm{g}$ for ash, fat, protein, and water, respectively. The increased weight of fat-free lean in callipyge carcasses $(1.875 \mathrm{~kg} ; \mathrm{P}<.001)$ was offset by the decrease in fat weight (1.859 kg; $\mathrm{P}<.001)$, suggesting little, if any, effect on bone weight. Callipyge carcasses consisted of $24.3 \%$ fat and $71.3 \%$ fat-free lean, compared with 31.5 and $64.0 \%$, respectively, for normal carcasses of the same weight. The relationships of fat and fat-free lean percentages with carcass weight are displayed in Figure 3.

Subcutaneous fat depth is an economically relevant characteristic in value-based marketing systems in the United States and abroad. Relationships of compositional traits with fat depth at the 12th rib were therefore investigated (Table 4). At the mean of $.491 \mathrm{~cm}$ of fat depth, callipyge lambs were $15.4 \mathrm{~d}$ older
$(\mathrm{P}<.01)$ and produced carcasses that averaged 4.113 $\mathrm{kg}$ heavier $(P<.001)$ than those of normal lambs. The heavier carcass weight was associated with an insig-

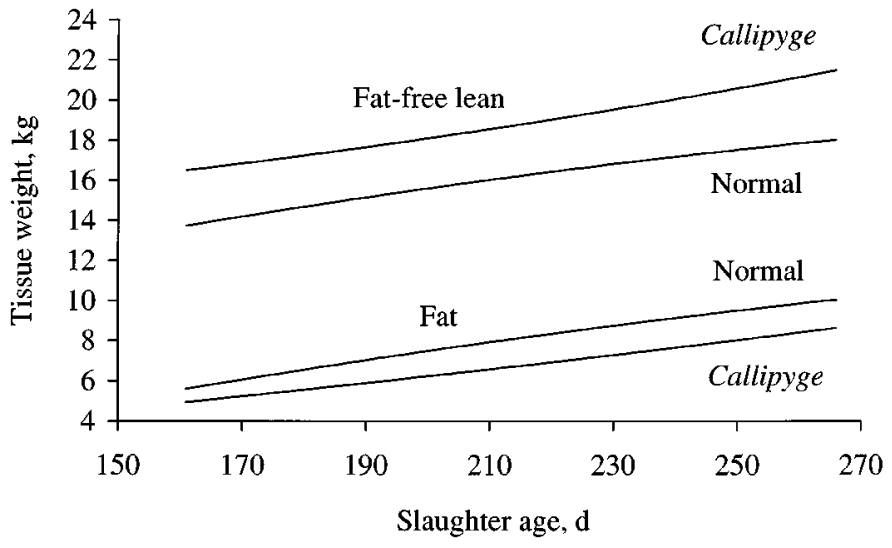

Figure 2. Relationships of carcass fat and fat-free lean tissue with slaughter age of callipyge (CN) and normal (CC, NC, NN) phenotypic (genotypic) groups. 


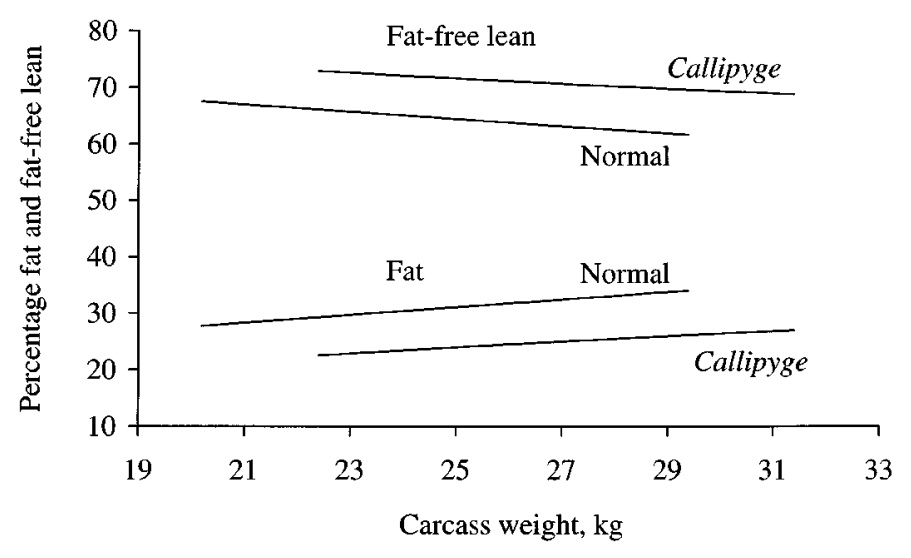

Figure 3. Relationships of percentages fat and fat-free lean with carcass weight of callipyge $(\mathbf{C N})$ and normal (CC, NC, NN) phenotypic (genotypic) groups.

nificant decrease of $33 \mathrm{~g}$ of fat and an increase ( $\mathrm{P}<$ .001 ) of $4.024 \mathrm{~kg}$ of fat-free lean; that is, fat-free lean accounted for virtually the entire increase in carcass weight. At the mean fat depth, the fat percentage of normal carcasses was $30.8 \%$, compared with $26.5 \%$ for callipyge carcasses ( $P<.001$ ). Normal carcasses at 29 $\mathrm{kg}$, the carcass weight of callipyge lambs with $.491 \mathrm{~cm}$ of fat depth, are predicted to contain $33.7 \%$ fat (F igure $3)$. The relationships of slaughter age, carcass weight, and percentage fat over the appropriate range of fat depths at the 12th rib are shown in Figures 4, 5, and 6 , respectively.

\section{Distribution of Carcass Components}

To evaluate the hypotheses that callipyge and normal carcasses had similar distributions of protein or fat, the component weight of each section was regressed on the component weight of the carcass (Table 5). These analyses directly estimated the proportion of the total carcass component that existed within each of the three sections. When evaluated at $3.991 \mathrm{~kg}$ of carcass protein, callipyge carcasses had 47 g more posterior protein $(P<.001), 11 \mathrm{~g}$ more middlesection protein $(P>.05)$, and $59 \mathrm{~g}$ less anterior protein $(P<.001)$ than normal carcasses. This shift amounts to an increase of $1.2 \%$ of the carcass protein in the posterior section (38.4 vs $37.2 \%$ ) and a decrease of $1.5 \%$ in the anterior section (33.3 vs $34.8 \%)$ of callipyge lambs. The middle section of normal and callipyge carcasses contributed to carcass protein in a similar fashion. Callipyge carcasses had greater carcass protein at the same age or carcass weight and a slightly greater proportion of carcass protein was located in the posterior section.

Distribution of carcass fat indicated that the contribution by each section was similar between genotypic groups at the mean value of $7.584 \mathrm{~kg}$ of carcass fat. Callipyge carcasses had less carcass fat at the same age or same carcass weight, but the relative contribution to the carcass fat by the three sections was similar to that of normal lambs. Kidney-pelvic fat, which was not included as a component of carcass fat, and fat depth at the fourth sacral vertebra were similar for the genotypic groups when compared at the same value of carcass fat. However, 12th-rib fat depth was less in callipyge carcasses than in normal carcasses with the same amount of carcass fat $(P<$ $.001)$. This would indicate a shift in the distribution of fat away from this subcutaneous fat depot in callipyge carcasses.

\section{Discussion}

Interpretation and application of results reported herein are in the context of a genetic background of Dorset and Romanov germplasm. The production system used a drylot setting in which lambs were fed a high-concentrate diet. Slaughter ages and live weights that are represented go beyond typical industry values for this type of crossbred lamb. This is the first experiment designed to estimate effects of all four CLPG genotypes on growth, slaughter, and carcass traits. We are currently completing experiments to evaluate the effects of these four CLPG genotypes on meat quality traits. Comprehensive evaluations of CLPG genotypic effects in additional environments, marketing conditions, and genetic backgrounds seem appropriate.

Gene action and effects of CLPG would favor its use in terminal sire mating systems. I mportant aspects to consider in the evaluation of terminal sire populations include survival rate, growth rate, and carcass composition of crossbred progeny. No evidence of divergence

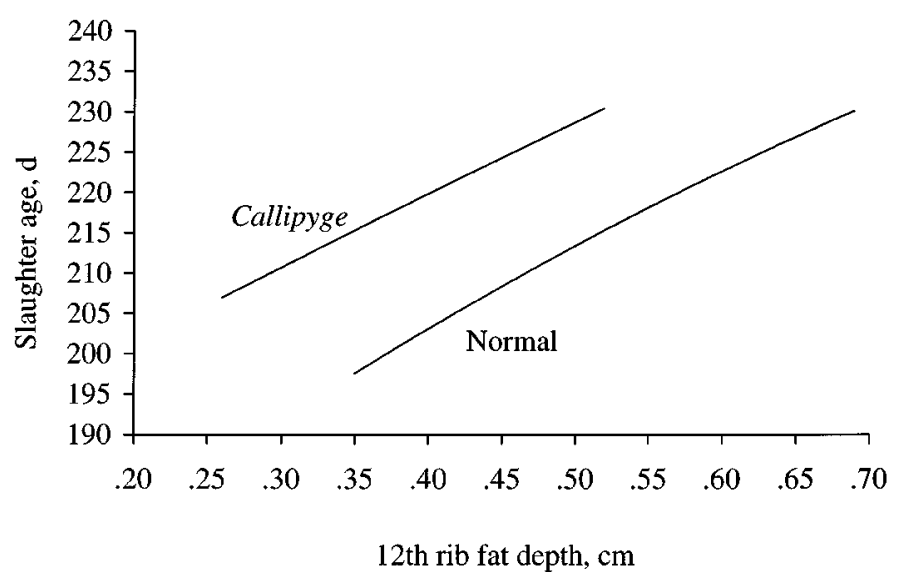

Figure 4. Relationship of slaughter age with 12th-rib fat depth of callipyge (CN) and normal (CC, NC, NN) phenotypic (genotypic) groups. 


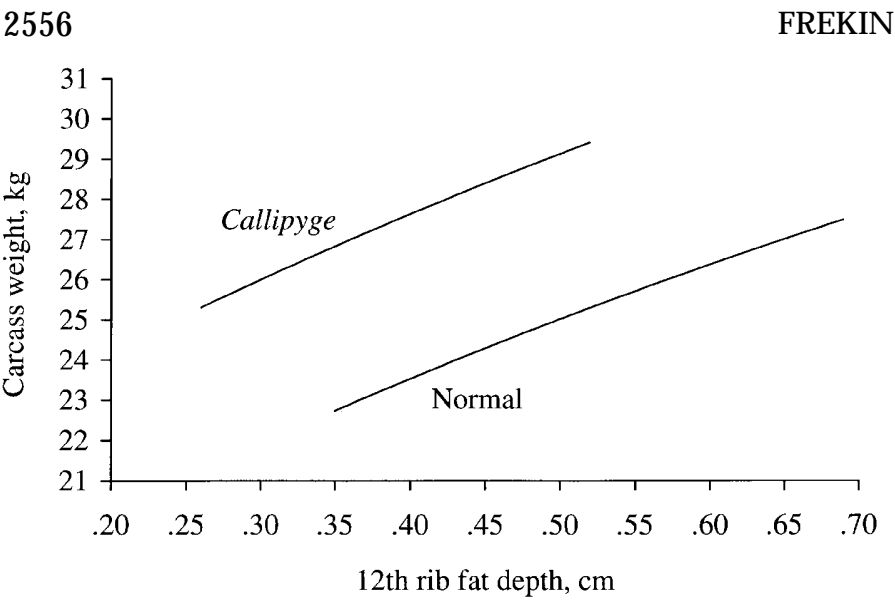

Figure 5. Relationship of carcass weight with 12th-rib fat depth of callipyge (CN) and normal (CC, NC, NN) phenotypic (genotypic) groups.

from expected frequencies of CLPG genotypes was detected in the $F_{2}$ lambs. Using flanking marker information to infer the most likely CLPG genotype, $11.8,21.7,31.2$, and $35.2 \%$ of the $F_{2}$ lambs born were CC, NC, CN, and NN genotypes, respectively. Using known allelic frequency of $F_{1}$ sires (seven heterozygotes and one noncarrier based on progeny test) and an estimate of .33 for $\mathbf{C}$ allele frequency of $F_{1}$ dams (two-thirds were classified as expressing the callipyge phenotype), the corresponding expectations of progeny genotypes are $14.8,18.2,30.2$, and $36.8 \%$ for CC, NC, CN, and NN genotypes, respectively. These data, in addition to the 9\% preweaning losses randomly distributed among CLPG genotypes, would suggest that the CLPG gene does not affect prenatal or postnatal survival.

The CLPG genotypes did not affect any measure of growth. These results are consistent with those of J ackson et al. (1997a), who report that no differences were detected between callipyge phenotypes for birth weight, weaning weight, and postweaning daily gain. However, compositional targets for callipyge sheep can be achieved at greater live and carcass weights. These results imply an unusual situation, in which carcass composition is changed dramatically without affecting growth patterns. A general interbreed relationship exists among growth rate, mature size, and carcass composition; breeds that exhibit greater growth rate and heavier mature weight yield leaner carcasses at the same age relative to other breeds ( $\mathrm{McCl}$ elland and Russel, 1972; Cameron and Drury, 1985). Besides callipyge, another exception to this general relationship is the Texel breed, which sires lambs of intermediate growth and mature weight, yet with carcass composition similar to that of North American Suffolksired lambs of the same weight (Leymaster and J enkins, 1993). Texel sheep also exhibit a similar onset of extreme muscle development typical of the callipyge phenotype. However, the Texel phenotype seems to result from polygenic effects rather than from segregation at a single locus. It would be of interest to test for interactions of CLPG alleles with different genetic backgrounds such as the Texel and Suffolk.

The substantial advantage in dressing percentage of callipyge lambs at the mean live weight, 55.9 vs $51.7 \%$, can be attributed in part to lower pelt, liver, and kidney-pelvic fat weights. Koohmaraie et al. (1995) did not detect a difference in pelt weight or kidney-pelvic fat but did report a significant decrease in liver, lung, and kidney weights from a smaller study with callipyge and normal Dorset lambs of similar age and live weight. Jackson et al. (1997b) did not detect differences in kidney-pelvic fat or internal organ weights, with the exception of decreased weight of large intestine, of nine callipyge compared with nine normal ram lambs of the Rambouillet breed slaughtered at a constant live weight. A positive correlation of weights of metabolically active internal organs with daily feed intake of sheep has been established (see review of Koong et al., 1985). Accordingly, the lighter weight of internal organs is consistent with the reduced daily feed intake of callipyge compared with normal lambs (J ackson et al., 1997a). J ackson et al. (1997a) reported that callipyge phenotype decreased 12-mo fleece weights of yearling Rambouillet ewes by approximately $18 \%$. These researchers hypothesized that dietary amino acids were preferentially converted to lean tissue growth rather than to wool growth. In the U.S. sheep industry, economic value of wool clip relative to carcass lean is low; however, fleece characteristics are relevant in the evaluation of the impact of CLPG genotypes.

Callipyge lambs deposited less fat at the 12th rib and fourth sacral vertebra and produced heavier

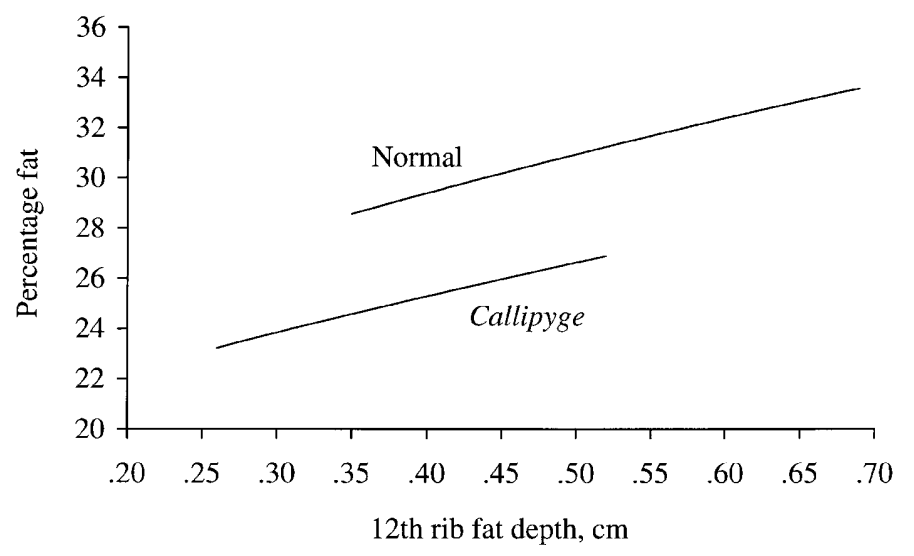

Figure 6. Relationship of percentage fat with 12th-rib fat depth of callipyge (CN) and normal (CC, NC, NN) phenotypic (genotypic) groups. 
Table 5. Regression equations representing distribution of carcass protein or carcass fat by polar overdominance genotypic group

\begin{tabular}{|c|c|c|c|c|c|c|c|c|}
\hline \multirow[b]{2}{*}{ Trait } & \multicolumn{3}{|c|}{ Callipyge ( $\mathbf{C N}$ genotype) } & \multicolumn{3}{|c|}{ Normal (CC, NC, NN genotypes) } & \multirow{2}{*}{$\begin{array}{l}\text { Effect of callipyge } \\
\text { in residual SD }\end{array}$} & \multirow{2}{*}{$\begin{array}{l}\text { Percentage } \\
\text { variation }^{\mathrm{a}}\end{array}$} \\
\hline & Intercept & Linear & Quadratic & Intercept & Linear & Quadratic & & \\
\hline \multicolumn{9}{|l|}{ Carcass protein ${ }^{b}$} \\
\hline Anterior section protein, kg & 1.328 & .314140 & .007831 & 1.387 & .346925 & .005636 & $-.88 * * *$ & 1.02 \\
\hline Middle section protein, $\mathrm{kg}$ & 1.130 & .308119 & .004974 & 1.119 & .288621 & -.004996 & .18 & .13 \\
\hline Posterior section protein, $\mathrm{kg}$ & 1.532 & .377741 & -.012805 & 1.485 & .364454 & -.000639 & $.77^{* * *}$ & .42 \\
\hline \multicolumn{9}{|l|}{ Carcass fat ${ }^{\mathrm{C}}$} \\
\hline Anterior section fat, kg & 2.351 & .266624 & -.008042 & 2.395 & .295919 & -.000056 & -.24 & .39 \\
\hline Middle section fat, $\mathrm{kg}$ & 3.197 & .493476 & .011396 & 3.160 & .467033 & .001112 & .19 & .19 \\
\hline Posterior section fat, $\mathrm{kg}$ & 2.036 & .239900 & -.003354 & 2.030 & .237048 & -.001055 & .03 & .02 \\
\hline Kidney-pelvic fat, $\mathrm{kg}$ & 1.221 & .194949 & -.000212 & 1.263 & .179619 & -.005517 & -.14 & .23 \\
\hline 12th-rib fat, $\mathrm{cm}$ & .419 & .075174 & .005381 & .499 & .071668 & .002072 & $-.54 * * *$ & 1.43 \\
\hline $\begin{array}{l}\text { Fourth sacral vertebra fat, } \\
\mathrm{cm}\end{array}$ & 1.505 & .179105 & -.002081 & 1.503 & .145575 & -.001477 & .01 & .31 \\
\hline
\end{tabular}

aDifference in residual sums of squares on a percentage basis accounted for by $3 \mathrm{df}$ associated with polar overdominance contrast.

${ }^{b}$ Covariate values are deviations from the mean value of $3.991 \mathrm{~kg}$ carcass protein. The callipyge effect (actual units) at the mean value of carcass protein is the difference between callipyge and normal intercept values.

cCovariate values are deviations from the mean value of $7.584 \mathrm{~kg}$ of carcass fat. The callipyge effect (actual units) at the mean value of carcass fat is the difference between callipyge and normal intercept values.

$* * * \mathrm{P}<.001$.

carcasses than normal lambs before reaching similar levels of subcutaneous fat depth. Even at heavier weights, callipyge carcasses were significantly leaner. In fact, on average, callipyge carcasses did not even approach the fat depth boundary that separates USDA yield grades 2 and $3(.635 \mathrm{~cm}$ fat depth). The combination of higher dressing percentage, heavier carcasses, and lower subcutaneous fat levels would increase the value of callipyge carcasses to packers by reducing overhead and trimming costs per unit of carcass weight. Value-based marketing systems should reflect this advantage.

Even though the current USDA lamb yield grading system does not consider carcass conformation, a common assumption within the U.S. sheep industry is that consumer acceptance of lamb would improve by increasing longissimus muscle area, affecting product appearance in the retail case. Longissimus muscle area at the 12th rib was more than 2.5 residual SD units $\left(5 \mathrm{~cm}^{2}\right)$ greater in callipyge carcasses than in normal carcasses at age- and weight-constant end points. This effect, achieved in a one-half Romanov genetic background, was associated with similar increases in depth and width of the longissimus muscle at the 12th rib. The decreased length of callipyge carcasses may also contribute to this increase in surface area. Results indicate that callipyge carcasses are more compact in skeletal structure and exhibit a more pronounced muscle shape in the shoulder as well as the rump and leg.

Similar advantages in longissimus muscle area and carcass conformation of callipyge carcasses have been reported (Koohmaraie et al., 1995; Carpenter et al., 1996; J ackson et al., 1997b); however, direct compari- son of absolute values is difficult owing to varying experimental procedures, statistical precision, and germplasm sources. The CLPG genotypic effects presented herein are greater than reported breed effects from a variety of sire breed evaluations. The greatest difference in sire breed constants for longissimus muscle area independent of carcass weight reported by Wolf et al. (1980) was $1.11 \mathrm{~cm}^{2}$ (Texel minus Oldenburg). Kempster et al. (1987) estimated an advantage for Texel-sired lambs of $5.5 \mathrm{~mm}$ in longissimus muscle width and $1.9 \mathrm{~mm}$ in longissimus muscle depth compared with Southdown-sired and Hampshire-sired lambs, respectively. Leymaster and J enkins (1993) reported least squares means of longissimus muscle area of $15.5 \mathrm{~cm}^{2}$ for Texel-sired and $14.6 \mathrm{~cm}^{2}$ for Suffolk-sired progeny at $25-\mathrm{kg}$ carcass weight, which is similar to the $25.63-\mathrm{kg}$ mean weight of the current study.

It is clear from composition data that lean tissue was greater and fat tissue was less in callipyge carcasses before $23 \mathrm{wk}$ of age. The advantage of callipyge phenotype was slightly increased as age and carcass weight increased. Increased lean growth rate and decreased fat growth rate are therefore consequences of the mutant CLPG allele. The difference in percentage lean independent of carcass weight was substantial, with means of $71.3 \%$ for callipyge compared with $64.0 \%$ for normal carcasses. A $6.2 \%$ advantage in carcass lean for crossbred progeny of Texel- compared with Charmoise-sired lambs was the most extreme sire breed difference reported by Cameron and Drury (1985). Wolf et al. (1980) estimated a $5.8 \%$ lean advantage for Texel crossbred lambs compared with Dorset Down-sired progeny as the 
extreme comparison among six sire breeds. A large study identified the Texel as the most extreme sire breed for percentage carcass lean with a 1.9 to 3.3\% advantage over Hampshire, Dorset Down-, or Ile de France-sired progeny depending on production environment (Croston et al., 1987; Kempster et al., 1987). These literature comparisons highlight the relative magnitudes of the CLPG genotypic effects, which are greater than the most extreme reported differences of sire breeds for carcass composition.

The callipyge phenotype may create changes in the muscle distribution of lamb carcasses. J ackson et al. (1997c; Table 8) reported that nine callipyge carcasses had a greater percentage of weight of selected muscles in the pelvic limb (1.5\%) and torso (1.9\%), with a corresponding decrease in the thoracic limb (3.4\%) relative to nine normal carcasses. In the present study, the percentages of carcass protein deposited in the anterior, middle, and posterior sections were $33.3,28.3$, and $38.4 \%$, respectively, for callipyge carcasses; corresponding values for normal carcasses were $34.8,28.0$, and $37.2 \%$. Relative to normal carcasses, the protein distribution of callipyge carcasses decreased $1.5 \%$ in the anterior section and increased .3 and $1.2 \%$ in the middle and posterior sections. A shift of protein from the anterior to the posterior section was statistically detected but is unlikely of economic significance. When the entire carcass was considered rather than selected muscles, there was less-convincing evidence that CLPG genotypes caused a major shift in distribution of carcass protein away from the anterior section to the middle and posterior sections. Hypertrophy of muscle tissue is perhaps more noticeable in, but not limited to, the major muscles of the loin and pelvic girdle.

With the exception of 12th-rib fat depth, fat distribution was not affected by CLPG genotypic groups when evaluated at common levels of total carcass fat. Callipyge carcasses had less carcass fat at age- and weight-constant end points, and the development of all fat depots was delayed. The significant difference in 12th-rib fat depth estimated at constant carcass fat was less than $1 \mathrm{~mm}$.

Even though carcass composition is only one aspect to consider in the evaluation of CLPG genotypes, the dramatic improvement that can be realized from its use in simplistic mating systems would have significant impact on the production of lean lamb. Additional questions that have not been adequately investigated include CLPG genotypic effects on reproduction, feed efficiency, and meat quality. Studies that address feed intake and reproduction are currently underway at MARC. Research on meat quality issues associated with callipyge phenotypes have been reported (Koohmaraie et al., 1995; Carpenter et al., 1996; Field et al., 1996). Studies to address effects of all four CLPG genotypes on meat quality traits are also being completed at MARC.

\section{Implications}

Specific callipyge ( CLPG) genotypes can be used in structured mating systems to make dramatic improvements in dressing percentage, lean growth rate, muscle shape, and carcass composition. Lambs can be taken to much greater carcass weights and still produce leaner carcasses. Increased carcass value, from the producer and the packer perspectives, would be associated with spreading fixed costs over more Iean retail product. Genetic diversity between breeds allows sheep crossbreeding systems to set reproduction at the desired rate, and CLPG could be considered to improve carcass value of progeny of terminal sires.

\section{Literature Cited}

AOAC. 1990. Official Methods of Analysis (15th Ed.). Association of Official Analytical Chemists, Arlington, VA.

Cameron, N. D., and D. J . Drury. 1985. Comparison of terminal sire breeds for growth and carcass traits in crossbred lambs. Anim. Prod. 40:315-322.

Carpenter, C. E., O. D. Rice, N. E. Cockett, and G. D. Snowder. 1996. Histology and composition of muscles from normal and callipyge lambs. J. Anim. Sci. 74:388-393.

Cockett, N. E., S. P. J ackson, T. L. Shay, F. Farnir, S. Berghmans, G. D. Snowder, D. M. Nielsen, and M. Georges. 1996. Polar overdominance at the ovine callipyge locus. Science 273: 236-238.

Cockett, N. E., S. P. J ackson, T. L. Shay, D. Nielsen, S. S. Moore, M. R. Steele, W. Barendse, R. D. Green, and M. Georges. 1994 Chromosomal localization of the callipyge gene in sheep (Ovis aries) using bovine DNA markers. Proc. Natl. Acad. Sci. USA 91:3019-3023.

Croston, D., A. J . Kempster, D. R. Guy, and D. W. J ones. 1987. Carcass composition of crossbred lambs by ten sire breeds compared at the same carcass subcutaneous fat proportion. Anim. Prod. 44:99-106.

Field, R. A., R. J . McCormick, D. R. Brown, F. C. Hinds, and G. D. Snowder. 1996. Collagen crosslinks in longissimus muscle from lambs expressing the callipyge gene. J. Anim. Sci. 74: 2943-2947.

Freking, B. A., J. W. Keele, C. W. Beattie, S. M. Kappes, T.P.L. Smith, T. S. Sonstegard, M. K. Nielsen, and K. A. Leymaster. 1998. Evaluation of the ovine callipyge locus: I. Relative chromosomal position and gene action. J. Anim. Sci. 76: 2062-2071.

J ackson, S. P., and R. D. Green. 1993. Muscle trait inheritance, growth performance and feed efficiency of sheep exhibiting a muscle hypertrophy phenotype. J. Anim. Sci. 71(Suppl. 1):241.

J ackson, S. P., R. D. Green, and M. F. Miller. 1997a. Phenotypic characterization of Rambouillet sheep expressing the Callipyge gene: I. Inheritance of the condition and production characteristics. J. Anim. Sci. 75:14-18.

J ackson, S. P., M. F. Miller, and R. D. Green. 1993a. The effect of a muscle hypertrophy gene on muscle weights of ram lambs. J . Anim. Sci. 71(Suppl. 1):146.

J ackson, S. P., M. F. Miller, and R. D. Green. 1997b. Phenotypic characterization of Rambouillet sheep expressing the Callipyge gene: II. Carcass characteristics and retail yield. J . Anim. Sci. 75:125-132.

J ackson, S. P., M. F. Miller, and R. D. Green. 1997c. Phenotypic characterization of Rambouillet sheep expressing the Callipyge 
gene: III. Muscle weights and muscle weight distribution. J . Anim. Sci. 75:133-138.

J ackson, S. P., M. F. Miller, R. D. Green, and K. S. Brdecko. 1993b. Carcass characteristics of Rambouillet ram lambs with genetic muscle hypertrophy. J. Anim. Sci. 71(Suppl. 1):147.

Kempster, A. J., D. Croston, D. R. Guy, and D. W. J ones. 1987. Growth and carcass characteristics of crossbred lambs by ten sire breeds, compared at the same estimated carcass subcutaneous fat proportion. Anim. Prod. 44:83-98.

Koohmaraie, M., S. D. Shackelford, T. L. Wheeler, S. L. Lonergan, and M. E. Doumit. 1995. A muscle hypertrophy condition in lamb (callipyge): Characterization of effects on muscle growth and meat quality traits. J. Anim. Sci. 73:3596-3607.
Koong, L. J ., C. L. Ferrell, and J . A. Nienaber. 1985. Assessment of interrelationships among levels of intake and production, organ size and fasting heat production in growing animals. J. Nutr. 115:1383-1390.

Leymaster, K. A., and T. G. J enkins. 1993. Comparison of Texel- and Suffolk-sired crossbred lambs for survival, growth, and compositional traits. J. Anim. Sci. 71:859-869.

McClelland, T. H., and A.J .F. Russel. 1972. The distribution of body fat in Scottish Blackface and Finnish Landrace lambs. Anim. Prod. 15:301-306.

Wolf, B. T., C. Smith, and D. I. Sales. 1980. Growth and carcass composition in the crossbred progeny of six terminal sire breeds of sheep. Anim. Prod. 31:307-313. 